\title{
Peran Trait Mindfulness terhadap Psychological Well-Being pada Dewasa Awal
}

\author{
Anna Erpiana, Endang Fourianalistyawati \\ Universitas YARSI, Jl. Letjend Suprapto Kav. 13 Jakarta Pusat \\ e-mail: aerpiana@gmail.com
}

\begin{abstract}
During the early adulthood stage of development, there are duties that individuals typically perform, work and marriage. These duties must be balanced to obtain psychological well-being. If someone unable to balance both roles, they may get stress, unhappy, even the psychological well-being may decrease. One way to enhance psychological wel-being is trait mindfulness. The purpose of this study was to analyze the role of trait mindfulness on every dimension of psychological well-being in early adults. Samples were working and married adults between 20 40 years old and living in Jakarta-Bogor-Depok-Tangerang-Bekasi. This research used Ryff's Psychological Well-Being Scale to measure psychological well-being and Five Facet Mindfulness Questionnaire to measure trait mindfulness. Multiple regression testing showed trait mindfulness play a significant role in every dimension of psychological well-being, in which $35.3 \%$ for environmental mastery, $31.7 \%$ for purpose in life, $31.1 \%$ for positive relation, $24 \%$ for personal growth, $18.7 \%$ for autonomy, and $17.6 \%$ for self-acceptance.
\end{abstract}

Keywords: trait mindfulness, psychological well-being, stage of young adulthood development

\begin{abstract}
Abstrak
Individu dewasa awal memiliki dua tugas perkembangan utama, yaitu bekerja dan menikah. Kedua tugas perkembangan ini harus seimbang untuk meningkatkan psychological well-being. Apabila individu tidak mampu menyeimbangkannya, dapat menyebabkan stres dan ketidakbahagiaan bahkan menurunkan psychological well-being. Salah satu pendekatan untuk meningkatkan psychological well-being adalah trait mindfulness. Penelitian ini bertujuan menganalisis peran trait mindfulness terhadap setiap dimensi psychological well-being pada dewasa awal. Subjek berjumlah 200 orang yang merupakan individu dewasa awal dengan rentang usia 20-40 tahun, telah bekerja dan menikah, serta berdomisili di Jakarta-Bogor-DepokTangerang-Bekasi. Alat ukur terdiri dari Ryff's Psychological Well-Being Scale (PWBS) untuk mengukur psychological well-being, dan Five Facet Mindfulness Questionnaire (FFMQ) untuk mengukur trait mindfulness. Uji regresi ganda menunjukkan trait mindfulness berperan signifikan terhadap dimensi psychological well-being, yaitu sebesar $35.3 \%$ pada dimensi environmental mastery, $31.7 \%$ pada dimensi purpose in life, $31.1 \%$ pada dimensi positive relation, $24 \%$ pada dimensi personal growth, $18.7 \%$ pada dimensi autonomy, dan $17.6 \%$ pada dimensi self-acceptance.
\end{abstract}

Kata kunci: trait mindfulness, psychological well-being, tahap perkembangan dewasa awal

\section{Pendahuluan}

Tahap dewasa awal memiliki rentang usia antara 20-40 tahun (Erikson dalam Papalia, Feldman, \& Martorel, 2012). Menurut Newman dan Newman (2006), dua area utama dalam kehidupan dewasa awal, yaitu bekerja dan menikah. Sehingga, individu diharapkan untuk dapat menyeimbangkan kedua tugas tersebut.
Namun, telah diketahui bahwa sebesar $60 \%$ individu yang bekerja sulit untuk mendapat keseimbangan antara pekerjaan dan keluarga (Keene \& Quadagno, dalam Handayani, 2013). Individu dapat merasakan kelelahan, rasa bersalah, dan menguras energi untuk menyeimbangkan tuntutan dari kedua peran tersebut (Buzzanell, Meisenbach, Remke, Liu, Bowers, \& Conn, dalam Ariyanti, 2009). Peran keluarga 
dapat mengurangi jumlah waktu dan tenaga yang digunakan untuk peran pekerjaan, sehingga menimbulkan potensi terjadinya konflik dalam pekerjaan dan keluarga ikut merasakan dampaknya. Tuntutan pekerjaan membuat waktu dan tenaga untuk keluarga semakin berkurang dan menyebabkan konflik di lingkungan keluarga akibat waktu dan tenaga yang berkurang (Benin \& Niendstedt, dalam Christine, Oktorina, \& Mula, 2010). Dengan demikian, konflikkonflik tersebut menyebabkan stres yang berat, mengganggu aktivitas serta kesehatan individu, depresi, kegelisahan dan akhirnya membuat diri individu tidak bahagia, bahkan menurunkan psychological well-being (kesejahteraan psikologis).

Psychological well-being adalah keadaan psikologis dari individu yang memiliki karakter positif pada penerimaan diri, hubungan dengan orang lain, otonomi, penguasaan lingkungan, tujuan hidup, dan pertumbuhan diri (Ryff \& Keyes, 1995). Psychological well-being berhubungan pula dengan macam-macam variabel yang melibatkan proses internal dan eksternal pada diri individu. Salah satu variabel tersebut adalah trait mindfulness, yang memperkuat atensi atau kesadaran. Pada penelitian sebelumnya, telah ditemukan bahwa psychological well-being memiliki hubungan yang positif dan signifikan dengan kelima dimensi trait mindfulness (Baer, Smith, Hopkins, Krietemeyer, \& Toney, 2006).

Trait mindfulness adalah suatu bentuk disposisi dari mindfulness (Neelarambam, 2015) atau suatu derajat atensi mindful pada individu (Brown, Ryan, \& Creswell, 2007). Sedangkan mindfulness berarti suatu keadaan ketika individu sadar akan dirinya, baik tempat maupun mental terhadap keadaan yang terjadi pada saat itu juga, serta tidak berfikir ataupun terpaku akan kejadian masa lalu maupun masa depannya, melainkan fokus akan keadaan sekarang (Baer, Smith, Lykins, Button, Krietemeyer, Sauer, Walsh, Duggan, \& Williams, 2008). Individu yang mindful akan memiliki tingkat stres yang rendah ketika menemui permasalahan sehari-hari, memiliki mental dan fisik yang sehat, kemampuan yang baik dalam sosial dan emosional, serta indikator lain dalam kualitas hidup dan psychological well-being (Weinsten, Brown, \& Ryan, 2009). Dengan demikian, individu mampu untuk memenuhi tugas dan permasalahan dalam tahapan perkembangannya dapat diatasi dengan baik.

Di Indonesia telah dilakukan beberapa penelitian terkait trait mindfulness terhadap beragam subjek dan ditemukan dapat meningkatkan kesejahteraan psikologis mereka, seperti pada ibu hamil, pengendara motor, dan juga remaja (Fourianalistyawati, Grasiaswaty, \& Uswatunnisa, 2018). Beberapa hasil penelitian terkait dengan trait mindfulness dan psychological well-being menunjukkan bahwa trait mindfulness mampu membuat psychological well-being individu menjadi lebih baik dalam dimensi kepuasan hidup, self-confidence, selfefficacy, self-compasion, sense of personal growth (Weare, 2014), dan dimensi otonomi (Parto \& Besharat, 2011). Penelitian Mahmoudzadeh, Mohammad khani, Dolatshahi, dan Moradi (2015) menunjukkan bahwa mindfulness memiliki hubungan yang positif dengan setiap dimensi psychological well-being. Penelitian sebelumnya menunjukkan bahwa trait mindfulness dapat meningkatkan psychological well-being dengan menurunkan pola pemikiran yang berulang dan melakukan penerimaan pada diri individu maupun apa yang terjadi pada dirinya (Ramel, Goldin, Carmona, \& McQuaid, dalam Mahmoudzadeh dkk., 2015). Dengan demikian, semakin individu bersikap mindful, maka ia akan semakin bisa untuk mendeteksi dirinya sendiri dari pemikiran yang negatif. Selain itu, individu yang memiliki trait mindfulness akan menekankan pada penerimaan dibandingkan dengan menjauhi terhadap apa yang terjadi pada diri individu maupun lingkungannya (Brown \& Ryan, dalam Mahmoudzadeh dkk., 2015). Hal ini 
berhubungan dengan dimensi pada psychological well-being, salah satunya yaitu selfacceptance. Penelitian terkait trait mindfulness di Indonesia yang dilakukan oleh Sanoveriana dan Fourianalistyawati (2017), juga menemukan bahwa trait mindfulness merupakan prediktor yang signifikan terhadap semua dimensi dari psychological well-being.

\section{Psychological Well-Being}

Psychological well-being adalah kemampuan individu dalam menghadapi tantangan dalam rangka berjuang untuk memfungsikan dirinya sendiri secara penuh dan menyadari talenta uniknya. Psychological well-being juga dapat diartikan sebagai suatu keadaan psikologis yang tidak hanya bebas dari penyakit mental, tetapi mengandung arti yang lebih luas, yaitu individu memiliki karakter yang positif pada penerimaan diri, hubungan dengan orang lain, otonomi, penguasaan lingkungan, tujuan hidup, dan pertumbuhan diri (Ryff \& Keyes, 1995).

Menurut Ryff (1989) psychological well-being terdiri dari enam dimensi. Dimensi pertama, yaitu self-acceptance, adalah ketika individu memiliki sikap positif terhadap diri sendiri, mengenali dan menerima segala aspek diri yang baik dan buruk serta merasa positif tentang masa lalunya. Dimensi kedua, yaitu positive relation with others, merupakan kondisi dimana individu memiliki hubungan yang hangat, memuaskan, dan saling percaya satu sama lain, memperhatikan kesejahteraan orang sekitarnya, mampu berempati dan mengasihi serta terlibat dalam hubungan timbal balik.

Selanjutnya dimensi ketiga, yaitu autonomy, adalah ketika individu memiliki determinasi diri dan bebas, mampu mengatasi tekanan sosial dengan tetap berpikir dan bertindak sesuai dengan keyakinan, mengatur perilaku dari dalam diri, serta mengevaluasi diri berdasarkan standar pribadi. Dimensi keempat, yaitu environmental mastery, adalah kemampuan individu untuk menguasai dan mengatur lingkungan, mengontrol aktivitas eksternal yang kompleks, menggunakan kesempatan secara efektif, memiliki kemampuan untuk memilih dan menciptakan konteks yang sesuai dengan kebutuhan dan nilai pribadi.

Dimensi kelima, yaitu purpose in life, merupakan individu yang memiliki tujuan dalam hidup dan perasaan terarah, merasakan makna dan tujuan dari kehidu-pan yang sedang dan telah dilaluinya serta mempunyai tujuan hidup. Dimensi terakhir, yaitu personal growth, yaitu individu dapat merasakan perkembangan yang berkelanjutan, melihat dirinya tumbuh dan berkembang, terbuka pada pengalaman baru, menyadari potensi dalam dirinya serta melihat peningkatan dalam diri, simpati dan pengertian.

\section{Trait Mindfulness}

Menurut Baer, Smith, Lykins, Button, Krietemeyer, Sauer, Walsh, Duggan, dan William (2008), trait mindfulness adalah suatu keadaan ketika individu sadar akan dirinya, baik tempat maupun mental terhadap keadaan yang terjadi pada saat itu juga, serta tidak berfikir ataupun terpaku akan kejadian masa lalu maupun masa depannya, melainkan fokus akan keadaan sekarang.

Menurut Baer dkk. (2008), trait mindfulness memiliki lima dimensi, yaitu observing, describing, acting with awareness, non-judging of inner experience, dan non-reacting to inner experience. Observing adalah bagaimana individu menyadari atau memperhatikan pengalaman internal dan eksternal, seperti sensasi, kognisi, emosi, penglihatan, suara, dan bau. Describing merupakan kemampuan individu untuk memberi label atau menjelaskan pengalaman internal dengan kata-kata. Kemudian dimensi lainnya, yaitu acting with awareness, memiliki definisi yaitu ketika individu mengalami suatu aktivitas pada satu moment dan kontras dengan bertingkah secara mekanis ketika fokus perhatian berada di tempat lain. 
Selanjutnya, dimensi non-judging of inner experience yaitu ketika individu mengambil suatu makna yang bukan merupakan evaluasi atas pemikiran dan perasaan. Dimensi kelima, yaitu nonreactivity to inner experience, adalah saat individu memiliki kecenderungan untuk mengizinkan pemikiran dan perasaan untuk datang dan pergi, tanpa terbawa olehnya maupun mengikutinya.

\section{Dewasa Awal}

Papalia dan Olds (1998) mendefinisikan dewasa awal sebagai suatu tahap perkembangan individu yang sedang berada pada puncaknya, karena berbagai keputusan penting memengaruhi kesehatan, karir, dan hubungan antar pribadi pada masa dewasa awal. Dewasa awal dimulai dari usia 20-40 tahun (Erikson dalam Papalia, Feldman, \& Martorel, 2012). Papalia dan Olds (1998) telah membagi tiga tahapan pada masa dewasa awal, yaitu masa pembentukan (20-30 tahun), masa konsolidasi (30-40 tahun), dan masa transisi (40 tahun). Jadi, individu pada masa dewasa awal merupakan tahapan perkembangan yang memiliki berbagai keputusan penting untuk dipilih, terutama pada area bekerja dan menikah (Newman \& Newman, 2006)

\section{Bekerja}

Kerja adalah bagian yang penting bagi kehidupan manusia karena merupakan aspek kehidupan yang memberikan status kepada masyarakat (Brown, dalam Anoraga, 1988). Bekerja adalah kegiatan ekonomi yang dilakukan oleh seseorang dengan maksud memperoleh pendapatan atau keuntungan, paling sedikit 1 jam (tidak terputus) dalam seminggu yang lalu. (Badan Pusat Statistik, 2018). Tujuan dari bekerja adalah untuk memenuhi kebutuhan hidup individu, mendapatkan rasa aman, mencari kepuasan, dan dapat mengaktualisasikan diri dalam bekerja.

\section{Menikah}

Menikah adalah awal dari terbentuknya hubungan resmi antara pria dan wanita yang di dalamnya terdapat unsur keintiman, pertemanan, persahabatan, kasih sayang, pemenuhan hasrat seksual, dan menjadi lebih matang, serta penyatuan dua individu yang berlainan jenis dengan lahirnya anakanak (Papalia \& Olds, 1998). Sebelum menikah, individu akan melewati proses untuk memilih pasangan. Setelah menikah, individu akan membangun kehidupan rumah tangga dan menjaga komitmen untuk mempertahankan pernikahan (Copper \& Makin, dalam Wulandari 2009). Individu yang telah menikah, telah menyelesaikan salah satu dari tugas perkembangannya dan mendapatkan dukungan sosial yang lebih baik daripada yang belum menikah. Seperti pada penelitian Glenn (1975) yang menemukan bahwa seseorang yang telah menikah memiliki kebahagiaan secara menyeluruh dibandingkan dengan yang belum. Sehingga, menikah dapat meningkatkan psychological well-being pada diri individu.

\section{Metode Penelitian}

\section{Desain Penelitian}

Penelitian ini termasuk ke dalam penelitian asosiatif karena tujuan dari penelitian ini adalah untuk melihat ada atau tidaknya hubungan antara dua variabel dan arah dari hubungan tersebut (Sugiyono, 2011). Dalam penelitian ini dilakukan uji regresi untuk melihat hubungan fungsional antar variabel yaitu untuk melihat peran dari satu variabel terhadap variabel lainnya.

\section{Partisipan}

Penelitian ini menggunakan 200 individu dewasa awal yang memiliki rentang usia 20-40 tahun, telah bekerja dan menikah, serta berdomisili di JakartaBogor-Depok-Tangerang-Bekasi (Jabodetabek). Apabila ditinjau dari jenis kelamin, jumlah partisipan perempuan memiliki 
persentase $53 \%$ dan laki-laki memiliki persentase $47 \%$. Pada tahap perkembangan dewasa awal masa konsolidasi memiliki jumlah yang lebih banyak (61\%), dibandingkan dengan masa pembentukan (39\%).

\section{Instrumen Penelitian}

Psychological Well-Being Scale (PWBS). Psychological Well-Being Scale adalah alat ukur yang mengukur psychological well-being yang terdiri dari 42 item, dengan 22 item positif dan 20 item negatif. Setiap dimensi yaitu: selfacceptance, positive relation with others, autonomy, environ-mental mastery, purpose in life, dan personal growth masing-masing terdiri dari 7 item.

Hasil uji validitas terhadap instrumen PWBS, menunjukkan beberapa item yang perlu dihapus. Pada dimensi selfacceptance terdapat 4 item yang dihapus (item 18, 30, 36, 42). Kemudian, terdapat 1 item yang perlu dihapus pada dimensi autonomy (item 37), dimensi environmental mastery (item 8) dan dimensi purpose in life (item 41). Pada dimensi positive relation with others terdapat 2 item yang dihapus (item 9, 21). Total jumlah item yang digunakan dalam penelitian ini adalah 33 item.

Uji reliabilitas pada penelitian ini menggunakan analisis Cronbach's Alpha yang menghasilkan angka $\alpha=0,657$ pada dimensi self-acceptance, $\alpha=0,722$ pada dimensi positive relation with others, $\alpha=0,61$ pada dimensi autonomy, $\alpha=0,611$ pada dimensi environmental mastery, $\alpha=0,671$ pada dimensi purpose in life, dan $\alpha=0,642$ pada dimensi personal growth. Hasil uji reliabilitas tersebut menunjukkan bahwa dimensi-dimensi pada instrumen PWBS sudah reliabel karena memenuhi koefisien reliabilitas yang dianggap baik, yaitu di atas 0,6 (Sugiyono, 2011).
Five Facets of Mindfulness Questionnaire (FFMQ). Five Facet Mindfulness Questionnaire (FFMQ) adalah alat ukur untuk mengukur trait mindfulness. FFMQ ini terdiri dari 39 item dengan 20 item positif dan 19 item negatif, dengan rincian 8 item untuk tiap dimensi observing, describing, acting with awareness, dan non-judging of inner experience, serta 7 item untuk dimensi non-reactivity to inner experience.

Hasil dari uji validitas yang dilakukan terhadap FFMQ, menunjukkan bahwa terdapat 5 item yang perlu dihapus yaitu item pada nomor $2,7,27,32$, dan 37. Oleh karena itu, total jumlah item yang digunakan dalam penelitian ini adalah 34 item.

Hasil uji reliabilitas menggunakan analisis Cronbach's Alpha pada dimensi observing sebesar $\alpha=0,621$, dimensi describing sebesar $\alpha=0,737$, dimensi acting with awareness sebesar $\alpha=0.880$, dimensi non-judging sebesar $\alpha=0.682$, dan dimensi non-reactivity sebesar $\alpha=759$. Hasil uji reliabilitas tersebut menunjukkan bahwa dimensi-dimensi pada instrumen PFMQ sudah reliabel karena memenuhi koefisien reliabilitas yang dianggap baik, yaitu di atas 0,6 (Sugiyono, 2011).

\section{Prosedur Penelitian}

Sebelum pengambilan data, peneliti melakukan uji keterbacaan terhadap tiga partisipan dan mengujicobakan kedua instrumen kepada 80 responden yang sesuai dengan karakteristik subjek penelitian ini. Setelah mendapatkan nilai validitas dan reliabilitas yang baik, peneliti melakukan penyebaran data kepada 200 partisipan dengan memberikan kuesioner secara langsung kepada partisipan. Setelah data terkumpul, dilakukan olah data dan analisis regresi berganda. 


\section{Hasil Penelitian dan Pembahasan}

Tabel 1.

Data Deskriptif Variabel Trait Mindfulness

\begin{tabular}{lcccc}
\hline Dimensi & Skor minimum & Skor maksimum & Skor rata-rata & SD \\
\hline Observing & 9 & 40 & 24.1 & 5.29 \\
Describing & 4 & 15 & 10.075 & 2.32 \\
Acting with awareness & 10 & 40 & 27.965 & 5.31 \\
Non-judging & 8 & 39 & 25.625 & 4.79 \\
Non-reactivity & 10 & 34 & 20.755 & 4.02 \\
\hline
\end{tabular}

Tabel 2.

Data Deskriptif Variabel Psychological Well-Being

\begin{tabular}{lcccc}
\hline Dimensi & Skor minimum & Skor maksimum & Skor rata-rata & SD \\
\hline Self-acceptance & 8 & 18 & 13.955 & 2.55 \\
Positive relation & 16 & 42 & 30.99 & 5.72 \\
Autonomy & 15 & 35 & 23.72 & 4.08 \\
Environmental mastery & 16 & 36 & 24.635 & 4.26 \\
Pupose in life & 16 & 36 & 27.39 & 5.23 \\
Personal growth & 11 & 30 & 20.535 & 4.04 \\
\hline
\end{tabular}

Tabel 3.

Hasil Analisis Regresi Berganda Trait Mindfulness terhadap Psychological Well-Being

\begin{tabular}{lcccccc}
\hline \multicolumn{7}{c}{ Dimensi psychological well-being } \\
\cline { 2 - 7 } & $\begin{array}{c}\text { Environmental } \\
\text { mastery }\end{array}$ & $\begin{array}{c}\text { Purpose in } \\
\text { life }\end{array}$ & $\begin{array}{c}\text { Positive } \\
\text { relation }\end{array}$ & $\begin{array}{c}\text { Personal } \\
\text { growth }\end{array}$ & Autonomy & Self-acceptance \\
\hline $\mathrm{R}^{2}$ & .353 & .317 & .311 & .240 & .187 & .176 \\
$\mathrm{~F}$ & $21.202^{*}$ & $18.035^{*}$ & $17.511^{*}$ & $12.241^{*}$ & $8.924^{*}$ & $8.302^{*}$ \\
\hline$* \mathrm{p}<.05$ & & \multicolumn{5}{c}{}
\end{tabular}

Tabel 4.

Hasil Analisis Regresi Berganda Trait Mindfulness terhadap Psychological Well-Being Perdimensi

\begin{tabular}{|c|c|c|c|c|c|c|c|c|c|c|c|c|}
\hline \multirow{3}{*}{$\begin{array}{l}\text { Dimensi trait } \\
\text { mindfulness }\end{array}$} & \multicolumn{12}{|c|}{ Dimensi psychological well-being } \\
\hline & \multicolumn{2}{|c|}{$\begin{array}{c}\text { Self- } \\
\text { acceptance }\end{array}$} & \multicolumn{2}{|c|}{$\begin{array}{l}\text { Positive } \\
\text { relation }\end{array}$} & \multicolumn{2}{|c|}{ Autonomy } & \multicolumn{2}{|c|}{$\begin{array}{l}\text { Environmen- } \\
\text { tal mastery }\end{array}$} & \multicolumn{2}{|c|}{$\begin{array}{l}\text { Purpose in } \\
\text { life }\end{array}$} & \multicolumn{2}{|c|}{$\begin{array}{l}\text { Personal } \\
\text { growth }\end{array}$} \\
\hline & $\mathrm{B}$ & Sig. & $\mathrm{B}$ & Sig. & $\mathrm{B}$ & Sig. & $\mathrm{B}$ & Sig. & $\mathrm{B}$ & Sig. & $\mathrm{B}$ & Sig. \\
\hline Observing & .089 & $.026^{*}$ & .226 & $.006 *$ & .138 & $.030 *$ & .210 & $.000 *$ & .213 & $.005^{*}$ & .072 & .238 \\
\hline Describing & .183 & $.042 *$ & .105 & .566 & .215 & .130 & .090 & .496 & .174 & .298 & .013 & .925 \\
\hline $\begin{array}{l}\text { Acting with } \\
\text { awareness }\end{array}$ & .078 & .069 & .540 & $.000 *$ & .233 & $.001 *$ & .444 & $.000 *$ & .509 & $.000^{*}$ & .399 & $.000 *$ \\
\hline Non-judging & .018 & .700 & .108 & .271 & .081 & .290 & -.07 & .289 & -.08 & .341 & -.09 & .207 \\
\hline $\begin{array}{l}\text { Non- } \\
\text { reactivity }\end{array}$ & .162 & $.005 *$ & .165 & .159 & .139 & .126 & .138 & .105 & .175 & .103 & -.06 & .450 \\
\hline
\end{tabular}

\section{Asumsi Regresi Ganda}

Hasil regresi ganda dapat dikatakan valid, apabila memenuhi beberapa asumsi regresi ganda, seperti: normalitas, linieritas, homoscedasticity, dan multicollinearity.
Berdasarkan hasil analisis, ditemukan bahwa semua asumsi regresi ganda terpenuhi, yaitu data bersifat normal, linier, memiliki homoscedasticity, serta tidak memiliki multicollinearity antar variabel. 


\section{Hasil Analisis Regresi Berganda Trait Mindfulness terhadap Psychological Well-Being}

Berdasarkan hasil analisis regresi ganda pada tabel 3 telah ditemukan bahwa terdapat peran trait mindfulness terhadap setiap dimensi psychological well-being. Oleh karena itu, hipotesis pada penelitian ini diterima. Trait mindfulness berperan paling besar terhadap dimensi environmental mastery $\left(\mathrm{R}^{2}=0,353, \mathrm{p}<0,05\right)$, yaitu $35,3 \%$, dan berperan paling sedikit terhadap dimensi self-acceptance $\left(\mathrm{R}^{2}=0,176, \mathrm{p}<0,05\right)$.

\section{Pembahasan}

Berdasarkan hasil analisis penelitian ini, menunjukkan bahwa trait mindfulness berperan terhadap psychological well-being pada dimensi self-acceptance $\left(\mathrm{R}^{2}=0,176\right.$, $\mathrm{p}<0,05)$, positive relation $\left(\mathrm{R}^{2}=0,311\right.$, $\mathrm{p}<0,05)$, autonomy $\left(\mathrm{R}^{2}=0,187, \mathrm{p}<0,05\right)$, environmental mastery $\left(\mathrm{R}^{2}=0,353, \mathrm{p}<0,05\right)$, purpose in life $\left(\mathrm{R}^{2}=0,317, \mathrm{p}<0,05\right)$, dan personal growth $\left(\mathrm{R}^{2}=0,240, \mathrm{p}<0,05\right)$.

Trait mindfulness adalah bentuk disposisi dari individu yang memiliki karakteristik sadar akan dirinya, baik tempat maupun mental terhadap keadaan yang terjadi pada saat itu juga, serta tidak berfikir ataupun terpaku akan kejadian masa lalu maupun masa depannya, melainkan fokus akan keadaan sekarang (Baer dkk., 2008), dan self-acceptance adalah kondisi individu yang memiliki sikap positif terhadap diri sendiri, mengenali dan menerima segala aspek diri yang baik dan buruk serta merasa positif tentang masa lalunya (Ryff \& Keyes, 1995). Menurut Carson dan Langer (2006), ketika seseorang hidup dengan berfikir mindful, maka individu mampu untuk menerima masalah yang terjadi pada masa lalu maupun masa sekarang dari kehidupannya. Individu akan menyadari bahwa dirinya mampu untuk melihat kehidupannya dari berbagai perspektif dan ia mampu untuk mengubah perspektif tergantung dari konteksnya. Jadi, ketika seseorang dalam kondisi mindful maka individu dapat menerima dirinya sendiri dengan unconditionally. Ketika individu memiliki mindfulness, ia akan secara aktif membuat perbedaan sudut pandang atau perspektif mengenai lingkungan daripada memanipulasinya untuk membuat keuntungan dengan melakukan evaluasi positif dan menjaga self-esteem. Ketika individu secara aktif memberi perhatian kepada lingkungannya, berarti ia hidup dengan authentic pada saat itu. Selain itu, ketika individu melihat dirinya secara mindful, ia akan melihat bahwa dirinya adalah individu yang beraneka ragam dan potensi dalam dirinya tidak terbatas akibat persepktif yang dimiliki. Sehingga, selfacceptance adalah keputusan yang dibuat oleh individu ketika mengambil tanggung jawab akan hidupnya dan percaya bahwa ia dapat mengontrolnya berdasarkan keputusan yang ia buat untuk dunianya sendiri. Jadi, ketika individu bersikap mindful maka ia mampu untuk menerima dirinya tanpa syarat (Carson \& Langer, 2006).

Secara khusus dimensi pada trait mindfulness yang signifikan berperan terhadap dimensi self-acceptance pada psychological well-being adalah dimensi observing. Hal ini tidak sejalan dengan penelitian yang dilakukan oleh Sanoveriana dan Fourianalistyawati (2017) yang menemukan bahwa dimensi observing tidak secara signifikan menjadi prediktor terhadap psychological well-being. Menurut Carson dan Langer (2006), ketika individu mampu untuk melihat dan menyadari segala aspek yang terjadi dari berbagai perspektif, maka ia dapat menerima pengalaman dari masa lalu dan juga saat ini, sehingga ia bisa menerima dirinya sendiri secara apa adanya. Selanjutnya, dimensi pada trait mindfulness yang signifikan berperan terhadap dimensi self-acceptance adalah dimensi describing. Institute Meditation and Psychotherapy menemukan bahwa melakukan terapi mindfulness berguna untuk meningkatkan 
kesadaran akan pengalaman yang terjadi saat ini dengan sikap menerima (Germer, Siegel, \& Fulton, dalam Didonna, 2008). Ketika seseorang mengalami kesulitan, ia akan membutuhkan orang lain untuk memahami siapa dirinya dan mengapa ia menderita, sehingga seseorang harus mampu menjelaskan apa yang dipahami, serta melakukan penerimaan diri agar mampu untuk memberikan nasihat yang bermanfaat tanpa disalahpahami (Didonna, 2008). Selain itu, dimensi non-reactivity juga berperan terhadap self-acceptance karena pada individu yang dengan sengaja dan tegas agar menerima dirinya sendiri berusaha untuk tidak mengikuti atau berreaksi dengan pengalamannya (Rodriguez, 2015).

Selanjutnya, hasil penelitian ini menunjukkan bahwa trait mindfulness berperan secara signifikan terhadap dimensi positive relation. Positive relation adalah ketika individu memiliki hubungan yang hangat, memuaskan, dan saling percaya satu sama lain, memperhatikan kesejahteraan orang sekitarnya, mampu berempati dan mengasihi serta terlibat dalam hubungan timbal balik (Ryff, 1989). Menurut Davis dan Hayes (2011), trait mindfulness mampu memprediksi kepuasan dalam hubungan, memiliki kemampuan untuk merespon secara konstruktif terhadap relationship stress, dan kemampuan untuk mengidentifikasi dan komunikasi emosi terhadap partner termasuk mengenai konflik dalam hubungan, perasaan negatif, dan empati (Barnes, Brown, Krusemark, Campbell, \& Rogge; Wachs \& Cordova, dalam Davis \& Hayes, 2011). Barnes dkk. (Davis \& Hayes, 2011) menemukan bahwa individu dengan trait mindfulness yang tinggi memiliki emotional stress yang rendah dalam merespon konflik dalam hubungan dan mendiskusikan konflik tersebut dengan kemarahan dan kecemasan yang rendah. Fakta-fakta menunjukkan bahwa mindfulness memiliki hubungan dengan kemampuan untuk bertindak dengan kesadaran (act with awareness) dalam situasi sosial. (Dekeyser, Raes, Leijssen, Leyson, \& Dewulf, dalam Davis \& Hayes, 2011). Selain itu, mindfulness mampu mengubah struktur fisik dan fungsi dari otak, yang mampu meningkatkan fungsi asosiasi (Siegel, dalam Davis \& Hayes 2011), attention, sensory processing dan sensitivitas akan stimulus internal (Lazar dkk., dalam Davis \& Hayes, 2011), meningkatkan kecepatan proses dalam otak (Moore \& Malinowski, dalam Davis \& Hayes 2011), menurunkan task effort, serta memiliki lebih sedikit pemikiran yang tidak berhubungan dengan tugasnya (Lutz dkk., dalam Davis \& Hayes, 2011). Sehingga, akibat dari perubahan struktur fisik dan fungsi yang terjadi pada otak ketika individu dalam kondisi mindful mampu memengaruhi peningkatan kemampuan untuk bertindak secara sadar saat itu juga (Davis \& Hayes, 2011).

Dimensi trait mindfulness yang berperan signifikan terhadap dimensi positive relation with others pada psychological well-being adalah dimensi observing. Ketika seseorang telah terbiasa untuk mengenali apa yang terjadi pada dirinya sendiri, hal ini mampu meningkatkan kepekaan pada diri individu tersebut. Sehingga, dengan memanfaatkan kemampuannya tersebut, seseorang akan dengan mudah untuk memengaruhi dan menjalin hubungan dengan orang lain (Robert \& Cooper, dalam Agustian, 2001). Kemudian, dimensi pada trait mindfulness yang signifikan berperan terhadap dimensi positive relation with others pada psychological well-being adalah dimensi acting with awareness. Menurut Grotli (dalam Totlund, 2014), apabila individu memiliki kemampuan untuk melihat diri sendiri dan menyadari perilaku (acting) sendiri, maka hal ini akan meningkatkan kesadaran seseorang dalam hubungannya dengan orang lain.

Hasil penelitian ini juga menunjukkan bahwa trait mindfulness berperan secara signifikan terhadap dimensi autonomy. Autonomy adalah ketika individu memiliki 
determinasi diri dan bebas, mampu mengatasi tekanan sosial dengan tetap berpikir dan bertindak sesuai dengan keyakinan, mengatur perilaku dari dalam diri, serta mengevaluasi diri berdasarkan standar pribadi (Ryff, 1989). Ketika individu lebih atentif pada aktivitas yang menurutnya menarik, individu cenderung untuk merasakan pengalaman itu sebagai perasaan autonomy, dan mencapai level yang tinggi pada emosi yang menyenangkan dan level yang rendah pada emosi yang tidak menyenangkan. Autonomy adalah ketika individu berperilaku dan perilakunya tersebut secara penuh dikuasai oleh diri sendiri. Hasil penelitian yang dilakukan oleh Brown dan Ryan (2003) ini mengindikasikan bahwa ketika individu bertindak dengan mindful, individu akan bertindak sesuai dengan nilai dan minat yang dimiliki, hal ini seperti perasaan untuk memilih dengan perasaan yang senang atau nyaman dan dapat meningkatkan atensi mindful pada suatu tindakan (Langer, dalam Brown \& Ryan, 2003).

Selanjutnya, hasil penelitian ini menunjukkan bahwa trait mindfulness berperan secara signifikan terhadap dimensi environmental mastery. Environmental mastery adalah ketika individu mampu menguasai dan mengatur lingkungan, mengontrol aktivitas eksternal yang kompleks, menggunakan kesempatan secara efektif, memiliki kemampuan untuk memilih dan menciptakan konteks yang sesuai dengan kebutuhan dan nilai pribadi (Ryff, 1989). Menurut Huang (2015), mindfulness seperti meningkatkan kualitas dari informasi yang digunakan untuk membuat pilihan karena memiliki kesadaran dengan pemikiran yang terbuka dan mampu melakukan observasi, sehingga mindfulness mengurangi bias negatif seperti kecenderungan untuk lebih berat dalam mempertimbangkan informasi negatif daripada informasi positif. Jadi, mindfulness memberikan pilihan nyata untuk menyelesaikan dalam pembuatan keputusan dan menerangkan proses informasi mengenai kemungkinan satu dan lainnya seperti sensasi pada tubuh, perasaan dan perilaku. Mindfulness juga dapat memperbaiki pembuatan keputusan individu dengan berbagai cara selama proses membuat keputusan (Huang, 2015). Sehingga, semakin baik trait mindfulness yang dimiliki oleh individu, maka semakin baik pula kualitas individu dalam membuat suatu keputusan (environmental mastery).

Dimensi pada trait mindfulness yang berperan signifikan terhadap dimensi environmental mastery pada psychological well-being adalah dimensi observing. Ketika individu mengembangkan kemampuan untuk mengetahui secara jelas apa yang ia rasakan, ini adalah kontribusi yang penting untuk membuat individu menjadi nyaman untuk membuat pilihannya sendiri (NCCA, 2009). Kemudian, dimensi trait mindfulness yang berperan signifikan terhadap dimensi environmental mastery pada psychological well-being adalah dimensi acting with awareness. Hal ini sesuai dengan penelitian yang dilakukan oleh Diekman dan Preisendoerfer (dalam Kollmuss \& Agyeman, 2002) yang menunjukkan bahwa individu yang memiliki kesadaran dalam berperilaku akan dengan mudah menerima perubahan dan memperkuat perilakunya di lingkungan.

Selanjutnya, hasil penelitian ini menunjukkan bahwa trait mindfulness berperan secara signifikan terhadap dimensi purpose in life. Purpose in life adalah ketika individu memiliki tujuan dalam hidup dan perasaan terarah, merasakan makna dan tujuan dari kehidupan yang sedang dan telah dilaluinya serta mempunyai tujuan hidup (Ryff, 1989). Mindfulness mendorong individu untuk mengaitkan aktivitas yang lebih relevan dengan nilai yang dimilikinya, yang mana mendorong individu untuk mendapatkan bahwa hidupnya memiliki perasaan akan sebuah tujuan. Selain itu, dengan bersikap mindful, individu akan lebih baik untuk meregulasi dan mengontrol perilaku 
sehingga lebih baik untuk mendapatkan tujuannya (Semple, Lee, Rosa, \& Miller, 2010). Dari hasil penelitian Young (2014) mengungkapkan bahwa sesuatu dari mindfulness yang memengaruhi sebuah tujuan adalah aktivitas yang relevan dengan aktivitas yang cenderung menuju pada sebuah tujuan. Begitu juga menurut Hill, Sumner, dan Burrow (dalam Young, 2014), bahwa individu yang mengidentifikasi dan sadar akan aktivitasnya, akan bertindak sesuai dengan tujuannya untuk mendapatkan perasaan akan suatu tujuan.

Dimensi pada trait mindfulness yang berperan signifikan terhadap dimensi purpose in life pada psychological wellbeing adalah dimensi observing. Ketika individu belajar untuk mengobservasi kejadian yang berhubungan dengan bagian tubuh dan mengesksplorasinya menjadi sebuah insight baru ini memperlihatkan bahwa seseorang itu sebenarnya menunjukkan sebuah evaluasi akan respon yang mungkin akan mengembangkan sebuah tujuan (Mcknight \& Kashdan, 2009). Serta, dimensi pada trait mindfulness yang berperan signifikan terhadap dimensi purpose in life pada psychological well-being adalah dimensi acting with awareness. Ketika seseorang memiliki kesadaran untuk bertindak, maka ia akan melakukan refleksi dengan menjadi seseorang yang sadar dan mampu untuk mengungkapkan tujuan. Tujuan ini dapat dimunculkan dengan motivasi dari perilaku yang muncul berdasarkan kesadaran (Gray \& Jackendoff, dalam McKnight \& Kashdan, 2009).

Selain itu hasil penelitian ini juga menunjukkan bahwa trait mindfulness berperan secara signifikan terhadap dimensi personal growth. Personal growth adalah ketika individu merasakan perkembangan yang berkelanjutan, melihat dirinya tumbuh dan berkembang, terbuka pada pengalaman baru, menyadari potensi dalam dirinya serta melihat peningkatan dalam diri serta simpati dan pengertian (Ryff, 1989). Individu yang berada dalam kondisi mindful akan merasakan sensasi apapun yang menarik baginya, mampu untuk mengobservasi pola dari respon dan bereaksi terhadap apa yang terjadi, yang kemudian reaksi dan respon untuk merasakan suatu objek secara terusmenerus akan menjadi lebih lemah. Sehingga, individu akan lebih integratif, dan lebih bijaksana yang berkontribusi agar individu lebih memiliki respon yang efektif. Individu yang telah melakukan meditasi mindfulness melaporkan bahwa individu mampu mengobservasi alternatif pilihannya dengan baik, dan pada saat yang sama, individu tidak menyangka bahwa hal itu muncul oleh kapabilitas atau kemampuannya sendiri, sehingga ia merasa bahwa pengalamannya ini adalah pertumbuhan perasaan mengenai insight dan kebijaksanaan (Lehrer, Woolfolk, \& Sime, 2007).

Dimensi pada trait mindfulness yang berperan signifikan terhadap dimensi personal growth pada psychological wellbeing adalah dimensi acting with awareness. Ketika individu bertindak dengan kesadaran, maka ia akan meningkatkan perilaku empati dalam berinteraksi, sehingga kesadaran ini adalah hal yang terpenting untuk mendapatkan perubahan dan pertumbuhan (Corey \& Corey, dalam Myers, 2003).

Namun, trait mindfulness dimensi nonjudging of inner experience tidak memiliki peran yang signifikan terhadap setiap dimensi psychological well-being. Nonjudging of inner experience adalah ketika individu mengambil suatu makna yang bukan merupakan evaluasi atas pemikiran dan perasaan (Baer dkk., 2008). Pada penelitian-penelitian sebelumnya, seperti pada penelitian Cash dan Washington (dalam Soysa \& Wilcomb, 2013) yang menyatakan bahwa non-judging memprediksi psychological well-being, serta penelitian Baer dkk. (dalam Soysa \& Wilcomb, 2013) yang juga menyatakan bahwa describing, non-judging, dan nonreacting (dimensi trait mindfulness) 
berkontribusi untuk memprediksi psychological well-being. Perbedaan hasil penelitian ini diakibatkan oleh budaya Indonesia (kolektivistik) dengan budaya Barat (individualistik), seperti pada penelitian yang dilakukan oleh Masuda, Mesquita, Tanida, Ellsworth, Leu, dan Veerdonk (2008) dengan menggunakan sampel orang Asia (Jepang) dan Kaukasia (Amerika) yang menunjukkan bahwa orang Asia lebih fokus untuk melakukan judging terhadap perasaan dan informasi mengenai perasaan yang dirasakan oleh orang lain dibandingkan dengan orang Kaukasia. Selain itu, ketika orang Asia melihat emosi seseorang, ia juga akan melihat ke sekitarnya atau keseluruhan dari suatu kelompok, sedangkan orang Kaukasia menganggap bahwa emosi seseorang adalah milik tiap individu (Masuda dkk., 2008). Begitu juga pada penelitian yang dilakukan pada orang China dan Amerika yang menunjukkan bahwa orang China memiliki pemikiran perspektif yang lebih tinggi atau lebih sering untuk dilakukan dibandingkan dengan orang Amerika. Namun, yang membedakan bukanlah kemampuan dari pemikiran perspektifnya, melainkan level penggunaannya ( $\mathrm{Wu} \&$ Keysar, 2007). Dapat disimpulkan bahwa pola budaya dapat memengaruhi masalah attention kepada orang lain, dan budaya kolektivistik lebih sering melakukan judging baik mengenai perasaannya sendiri maupun kepada orang lain, sehingga dimensi non-judging tidak berperan terhadap psychological well-being di Indonesia.

Pada hasil penelitian ini mendukung beberapa penelitian sebelumnya bahwa trait mindfulness berperan terhadap psychological well-being. Namun, peranan ini tidak berlaku pada trait mindfulness dimensi non-judging. Hal ini merupakan hal baru yang telah ditemukan, yang mana budaya memengaruhi trait seseorang, sehingga dimensi ini adalah satu-satunya yang tidak memiliki peran terhadap psychological well-being pada dewasa awal yang telah bekerja dan menikah.

Pada hasil penelitian ini menunjukkan bahwa trait mindfulness berperan paling besar terhadap dimensi environmental mastery sebesar 35,3\%, dan paling kecil terhadap dimensi self-acceptance sebesar $17,6 \%$. Hal ini bertolak belakang dengan penelitian yang dilakukan oleh Mahmoudzadeh dkk. (2015), yaitu trait mindfulness berkorelasi paling besar terhadap dimensi self-acceptance dan paling kecil pada dimensi environmental mastery.

Menurut penelitian yang dilakukan oleh Langer (dalam Carson \& Langer, 2006) pada individu berusia 18-52 tahun menunjukkan bahwa individu sering melakukan perbandingan antara dirinya sendiri dengan orang lain. Hal ini menyebabkan individu lebih fokus akan hasil daripada proses. Apabila individu lebih mengutamakan hasil, maka ia akan sering merasa tidak puas karena individu cenderung untuk berusaha lebih atraktif, pintar, ataupun atletik. Dengan demikian, individu tidak dapat menerima dirinya sendiri secara apa adanya karena tidak authentic (Carson \& Langer, 2006). Dampak dari kebiasaan melakukan perbandingan yang sering dilakukan oleh individu yang berusia 18-52 tahun inilah yang mungkin dapat menyebabkan trait mindfulness memiliki peran yang paling rendah terhadap dimensi self-acceptance.

Sedangkan, trait mindfulness sering diasosiasikan dengan kesadaran akan dimana individu berada pada suatu tempat atau lingkungan. Dalam kesadaran ini terdapat unsur menerima kualitas diri dan tidak menghakimi diri sendiri (Kabat-Zinn dalam Ruedy \& Schweitzer, 2010) yang membuat individu memiliki atensi akan ide yang mungkin dapat muncul secara potensial pada diri individu. Menerima kualitas dan tidak melakukan penghakiman pada diri inilah yang menyebabkan trait mindfulness dapat mendorong untuk mempertimbangkan informasi yang relevan 
dalam membuat suatu keputusan. Sehingga, trait mindfulness dapat berperan besar terhadap environmental mastery karena mungkin dapat membantu individu secara signifikan untuk lebih sadar dalam mempertimbang-kan pembuatan keputusan (Ruedy \& Schweitzer, 2010).

Hasil penelitian ini telah memberikan pengetahuan baru mengenai trait mindfulness dan psychological well-being pada dewasa awal yang bekerja dan menikah. Sehingga dapat menjadi referensi untuk penelitian lain atau instansi tertentu dalam pemberian atau penerapan mindfulness untuk membantu meningkatkan psychological well-being pada dewasa awal. Meskipun penelitian ini telah dibuat sedemikian rupa, masih terdapat kekurangan dalam penelitian ini, seperti jumlah subjek yang tidak sebanding dengan jumlah populasi serta pengambilan subjek secara accidental. Hal ini memungkinkan hasil penelitian yang kurang baik. Sehingga, perlu dikembangkan kembali pada penelitian selanjutnya.

\section{Simpulan dan Saran}

\section{Simpulan}

Berdasarkan penelitian ini diperoleh simpulan bahwa empat dari lima dimensi yang terdapat pada trait mindfulness berperan signifikan terhadap setiap dimensi pada keenam dimensi psychological wellbeing. Pertama, dimensi observing, describing, dan non-reactivity to inner experience dari trait mindfulness berperan signifikan terhadap psychological wellbeing pada dimensi self-acceptance. Kedua, dimensi observing dan acting with awareness dari trait mindfulness menunjukkan peran yang signifikan terhadap empat dimensi lainnya dari psychological well-being yaitu dimensi positive relation with others, dimensi autonomy, dimensi environmental mastery, serta dimensi purpose in life. Ketiga, dimensi acting with awareness dari trait mindfulness berperan signifikan terhadap psychological well-being pada dimensi terakhir yaitu personal growth.

\section{Saran}

Penelitian selanjutnya dapat menambahkan variabel mediator antara trait mindfulness dan psychological wellbeing untuk lebih mengetahui secara mendalam bagaimana mekanisme trait mindfulness dapat berperan terhadap psychological well-being. Selain itu bagi para terapis diharapkan agar dapat memberikan pelatihan mindfulness bagi dewasa awal yang bekerja dan menikah untuk meningkatkan kesejahteraan psikologis, menurunkan stres, dan meningkatkan perilaku yang lebih adaptif dengan bersikap mindful.

\section{Daftar Pustaka}

Agustian, A. G. (2001). Rahasia sukses membangun kecerdasan emosi dan spiritual, ESQ (emotional spiritual quotient): The ESQ way 165 (1 ihsan 6 rukun iman dan 5 rukun Islam. Jakarta: Penerbit Arga.

Anoraga, P. (1988). Psikologi kerja. Jakarta: Rineka Cipta.

Ariyanti, E. S. (2009). Gambaran konflik peran pada ibu bekerja yang baru pertama kali memiliki anak (Skripsi). Universitas Indonesia, Depok.

Badan Pusat Statistik (BPS). (2018). Tenaga kerja. Diakses pada 19 Pebruari 2018 dari https://www.bps.go.id/subject/6/ten aga-kerja.html

Baer, R. A., Smith, G. T., Hopkins, J., Krietemeyer, J., \& Toney, L. (2006). Using self-report assessment methods to explore facets of mindfulness. Assessment, 13(1), 2745.

DOI: 10.1177/1073191105283504.

Baer, R. A., Smith, G. T., Lykins, E., Button, D., Krietemeyer, J., Sauer, 
S., Walsh, E., Duggan, D., \& Williams, J. M. G. (2008). Construct validity of the five facet mindfulness questionnaire in meditating and nonmeditating samples. Assessment, 15(3), 329342. DOI: 10.1177/1073191107313003.

Brown, K. W., \& Ryan, R. M. (2003). The benefit of being present: Mindfulness and its role in psychological well-being. Journal of Personality \& Social Psychology, 84(4), 822-848.

Brown, K. W., Ryan, R. M., \& Creswell, J. D. (2007). Mindfulness: Theoretical foundations and evidence for its salutary effects. Psychological Inquiry, 18(4), 211-237.

Carson, S. H., \& Langer, E. J. (2006). Mindfulness and self-acceptance. Journal of Rational-Emotive \& Cognitive-Behavior Therapy, 24(1), 29-43.

Christine, W. S., Oktorina, M., \& Mula, I. (2010). Pengaruh konflik pekerjaan dan konflik keluarga terhadap kinerja dengan konflik pekerjaan keluarga sebagai intervening variabel (studi pada dual career couple di Jabodetabek). Jurnal Manajemen dan Kewirausahaan, 12(2), 121-132.

Davis, D. M., \& Hayes, J. A. (2011). What are the benefits of mindfulness? A practice review of psychotherapyrelated research. American Psychological Association, 48(2), 198-208.

Didonna, F. (Ed.). (2008). Clinical handbook of mindfulness. New York: Springer. The National Institute for the Clinical Application of Behavioral Medicine. Diunduh dari

www.bpd.go.id/subjek/view/id/6.co $\mathrm{m}$

Fourianalistyawati, E., Grasiaswaty, N., \& Uswatunnisa,

A. (2018)
Confirmatory factor analysis of mindful attention awareness scale (MAAS) Indonesian version. Dipresentasikan pada Seminar Nasional Pascasarjana UGM 2018, Yogyakarta.

Glenn, N. D. (1975). The contribution of marriage to the psychological wellbeing of males dan females. Journal of Marriage and The Family, 37(3), 594-601.

Handayani, A. (2013). Keseimbangan kerja keluarga pada perempuan bekerja: Tinjauan teori Border. Buletin Psikologi (Universitas Gadjah Mada), 21(2), 90-101.

Huang, P. H. (2015). Empowering people to choose wisely by democratizing mindfulness and thinking tools. Diunduh dari https://ssrn.com/abstract=2639953

Kollmuss, A., \& Agyeman, J. (2002). Mind the gap: Why do people act environmentally and what are the barriers to pro-environmental behavior. USA: Tufts University.

Lehrer, P. M., Woolfolk, R.L., \& Sime, W.E. (2007). Principles and practice of stress management, 3rd Edition. New York: Guilford Press.

Mahmoudzadeh, S., Mohammadkhani, P., Dolatshahi, B., \& Moradi, S. (2015). Prediction of psychological well-being based on dispositional mindfulness and cognitive emotion regulation strategies in students. PCP, 3(3), 195-202.

Masuda, T., Mesquita, B., Tanida, S., Ellsworth, P. C., Leu, J., \& Veerdonk, E. V. D. (2008). Placing the face in context: Cultural differences in the perception facial emotion. Journal of Personality and Social Psychology, 94(3), 365-381.

McKnight, P. E., \& Kashdan, T. B. (2009). Purpose in life as a system that creates and sustains health and wellbeing: An integrative, testable 
theory. American Psychological Association, 13(3), 242-251.

Myers, S. (2003). Reflections on reflecting: How self-awareness promotes personal growth. Person-Centered Journal, 10(1-2), 3-22.

NCCA (National Council for Curriculum and Assesment). (2009). Creatchuraclam na luath-oitge (the early childhood curriculum framework). Ireland: 24 Merrion Square Dublin 2.

Neelarambam, K. (2015). Trait mindfulness as a mediator of resilience, depressive symptom, and trauma symptoms. Dissertation, Georgia State University: Department of Counseling and Psychological Service.

Newman, B. M., \& Newman, P. R. (2006). Development through life: A psychosocial approach, ninth edition. USA: Thomson Wadsworth

Papalia, D. E, Feldman, R. D., \& Martorel, G. (2012). Experience human development, 12th Ed. New York: McGraw-Hill Companies.

Papalia, D. E., \& Old, S. W. (1998). Human development. New York: McGraw Hill.

Parto, M., \& Besharat, M. A. (2011). Mindfulness, psychological wellbeing and psychological distress in adolescents: Assesing the mediating variables and mechanisms of autonomy and self-regulation. Procedia-Social and Behavioral Sciences, 30(2011), 578-582.

Rodriguez, M. A. (2015). Self-acceptance mediates the relationship between mindfulness and perceived stress. Psychol Rep., 116(2), 513-522. DOI: 10.2466/07.PR0.116k19w4.

Ruedy, N. F., \& Schweitzer, M. F. (2010). The effect of mindfulness on ethical decision making. Journal of Business Ethics, 95(1), 73-87.
Ryff, C. D., \& Keyes, C. L. M. (1995). The structure of psychological wellbeing revisited. Journal of Personality and Social Psychology, 69(4), 719-727.

Ryff, C. D. (1989). Happiness is everything, or is it? Explorations on the meaning of psychological wellbeing. Journal of Personality and Social Psychology, 57(6), 10691081.

Sanoveriana, A. S. N., \& Fourianalistyawati, E. (2017). Work-family balance, trait mindfulness and psychological well-being in middle-aged working parents. Universitas Indonesia Psychology Symposium for Undergraduate Research, 2016. Depok: Universitas Indonesia.

Semple, R. J., Lee, J., Rosa, D., \& Miller, L. F. (2010). A randomized trial of mindfulness-based cognitive therapy for children: Promoting mindful attention to enhance socialemotional resiliency in children. Journal of Child and Family Studies, 19(2), 218-229. DOI: 10.1007/s10826-009-9301-y.

Soysa, C. K., \& Wilcomb, C. J. (2013). Mindfulness, self-compasion, selfefficacy, and gender as predictors of depression, anxiety, stress, and well-being. Mindfulness, 6(2), 217226.

Sugiyono. (2011). Metode penelitian kuantitatif, kualitatif, dan $R \& D$. Bandung: Alfabeta.

Totlund, M. (2014). Leadership development program useful? Which influence/ impact have leadership development programs had to your development as a leader? (Thesis). Department of Adult Learning and Counselling, Norwegian University of Science and Technology.

Weare, K. (2014). Evidence for mindfulness: Impacts on the well- 
being and performance of school staff. UK: Mindfulness in Schools Project, in Association with University of Exeter.

Weinsten, N., Brown, K. W., \& Ryan, R. M. (2009). A multi-method examination of the effect of mindfulness on stress attribution, coping, and emotional well-being. Journal of Research, 43(3), 374385. DOI: 10.1016/j.jrp.2008.12.008.

Wu, S., \& Keysar, B. (2007). The effect of culture on perspective taking. Psychological Science, 18(7), 600606. DOI: $10.1111 /$ j.14679280.2007.01946.x.
Wulandari, D. A. (2009). Kajian tentang faktor-faktor komitmen dalam perkawinan. Psycho Idea, 7(1), 110.

Young, R. K. (2014). Mind your purpose: Intervening on mindfulness to promote daily levels of purpose (Thesis). Carleton University Ottawa, Ontario. 
Psympathic, Jurnal Ilmiah Psikologi Juni 2018, Vol. 5, No. 1, Hal: 67-82 